\title{
항중성구세포질항체 연관 혈관염에서 망막중심동맥 폐쇄, 급속진행토리콩팥염이 동반된 말초 다발신경병증: 증례보고
}

박승완, 류병주, 문정보, 곽호준, 김윤희

삼육서울병원 재활의학과

\section{A Case of Peripheral Polyneuropathy Presenting with Central Retinal Artery Occlusion, Rapid Progressive Glomerulonephritis due to ANCA Associated Vasculitis}

\author{
Seung-Wan Park, Byung-Ju Ryu, Jeong-Bo Moon, Ho-Jun Kwak, Yunhee Kim \\ Department of Physical Medicine and Rehabilitation, Sahmyook Medical Center, Seoul, Korea
}

\begin{abstract}
We report a case of asymmetric polyneuropathy with left central retinal artery occlusion, rapid progressive glomerulonephritis (RPGN) due to Antineutrophil cytoplasmic antibody (ANCA) associated vasculitis (AAV). A-64-year-old man started to have numbness and weakness in both legs. One month later, he suddenly lost a vision in his left eye and had swelling in both legs. Thereafter, weakness progressed to both upper extremities. Multiple eye retinal hemorrhages and cherry-red spots were observed on fundus examination and were diagnosed as central retinal artery occlusion. Pauciimmune crescentic glomerulonephritis were identified after renal biopsy. Nerve conduction study was performed and the patient was diagnosed by peripheral polyneuropathy involving both upper and lower extremities. Clinically, we diagnosed a vasculitis, especially microscopic polyangiitis (MPA).
\end{abstract}

Key Words: antineutrophil cytoplasmic antibody, central retinal artery occlusion, polyneuropathy

서 론

항중성구세포질항체 연관 혈관염(Antineutrophil cytoplasmic antibody associated vasculitis, AAV)은 주로 소

Received April 6, 2018

Revised May 16, 2018

Accepted June 1, 2018

Corresponding Author: Yunhee Kim

Department of Physical Medicine and Rehabilitation, Sahmyook Medical

Center, 82 Mangu-ro, Dongdaemun-gu, Seoul 02500, Korea

Tel: 82-2-2210-3133, Fax: 82-2-2210-3133, E-mail: yhkim76@hanmail.net
혈관에 염증을 유발하는 질환으로 다발혈관염육아종증 (granulomatosis with polyangiitis, GPA), 현미경적다발혈 관염(microscopic polyangiitis, MPA)과 다발혈관염호산구 육아종증(eosinophilic granulomatosis with polyangiitis, $\mathrm{eGPA}$ 로 구분된다. 각각의 진단은 발현하는 임상양상을 기 초로 하여 혈청학, 병리학적 검사를 종합하여 내릴 수 있다. ${ }^{1}$

$\mathrm{AAV}$ 로 인한 신경병증과 토리콩팥염은 흔하게 보고되고 있으나, AAV가 원인이 되어 망막중심동맥 폐쇄가 발생한 경 우는 국내에 보고된 바가 없다. 따라서 $\mathrm{AAV}$ 에 의한 편측 망 막중심동맥 폐쇄, 토리콩팥염, 그리고 다발신경병증이 병발
Copyright $\odot$ by Korean Association of EMG Electrodiagnostic Medicine
This is an Open Access article distributed under the terms of the Creative Commons Attribution Non-Commercial License (http://creativecommons.org/licenses/by-nc/4.0) which permits unrestricted non-commercial use, distribution, and reproduction in any medium, provided the original work is properly cited. 
한 증례를 $\mathrm{AAV}$ 에 대한 문헌고찰과 함께 보고한다.

\section{증 례}

64세 남자환자가 내원 2주 전 발생한 양측 하지의 위약과 감각이상을 주소로 내원하였다. 내원 1주 전부터는 보행이 불가능하고 누워서 다리를 들 수 없을 정도로 근력이 감소하 였다. 과거력에서 10년 전 고혈압을 진단받고 항고혈압제를 복용 중인 것 외에 특이사항은 없었다. 하지 근력 검사에서 우측 하지는 근위부 Poor+, 원위부 Poor grade였고, 좌측 하지는 근위부 Poor, 원위부 Trace grade로 좌측 하지의 위 약이 심하였다. 하지 감각 검사에서 양측 하지에서 Glovestocking 형태의 감각 저하가 관찰되었다. 상지에서는 근력 저하나 감각저하는 관찰되지 않았다. 양측 상하지의 심부건 반사는 모두 감소되어 있었고, 병적 반사는 관찰되지 않았 다. 환자의 의식은 명료하였고 판단력 및 지남력은 정상이 었으며, 배변장애 및 배뇨장애도 관찰되지 않았다. 신경외과 입원 이틀 후 시행한 요천추 MRI에서는 요추 4 번과 5 번의 척추협착증이 관찰되었다. 환자의 증상과 MRI 소견에 따라 2주 후 수술을 하기로 하고 집으로 퇴원하였다.

증상 발생 후 4주가 경과하였을 때 환자는 갑작스런 좌안 의 시력상실과 양측 하지의 부종을 호소하며 응급실로 내 원하였다. 내원 3일 전부터 거품뇨와 잔뇨감이 시작되었다 고 하였다. 좌안의 시력상실에 대해서 안저검사와 광간섭단 층영상(optical coherence tomography), 형광안저조영술 을 시행하였으며 다발성 망막출혈과 앵두반점(cherry-red spot)이 관찰되었고 망막중심동맥 폐쇄로 진단되었다(Fig. 1). 증상 발생 후 이미 8시간이 경과한 시점이어서 혈전용해 요법은 시행하지 못하였다. 당일 체온은 38도로 상승하였 고 양하지의 부종이 더욱 악화되었으며 혈뇨와 거품뇨가 관
찰되었다. 혈액검사에서 erythrocyte sedimentation rate (ESR) $160 \mathrm{~mm} / \mathrm{h}, \mathrm{C}$-reactive protein (CRP) $9.28 \mathrm{mg} / \mathrm{dL}$, white blood cell count (WBC) 13,710/ $\mu \mathrm{L}$, hemoglobin (Hb) $9.1 \mathrm{~g} / \mathrm{dL}$, BUN $40.7 \mathrm{mg} / \mathrm{dL}$, creatinine $5.45 \mathrm{mg} / \mathrm{dL}$, glomerular filtration rate (GFR) $44.7 \mathrm{~mL} / \mathrm{min} / 1.73 \mathrm{~m}$ 이 었고 소변검사에서 알부민 $3+$, 혈액 $3+$, 단백 $7,888 \mathrm{mg} / \mathrm{dL}$ 로 증가되어 있었다. 혈청검사에서 핵막 항중성구세포질항 체(perinuclear anti-neutrophilic cytoplasmic antibody, $\mathrm{P}-\mathrm{ANCA}$ ) > 600으로 양성 소견을 보였다. 신장 초음파에서 특이 사항은 보이지 않았으나, 신생검에서 pauci-immune crescentic glomerulonephritis을 보이는 급속진행토리콩 팥염(rapidly progressive glomerulonephritis, RPGN)으 로 진단되었다.

증상 발생 6주가 지난 시점에 양측 상지의 근력 저하 및 감각 저하가 발생하였다. 양측 상지의 근위부 근력 등급은 good grade, 우측 상지의 원위부는 Fair to Fair+ grade, 좌 측 상지의 원위부는 Fair- to Fair grade이었다. 근력의 약화 가 진행되어 시행한 좌측 상지 및 양측 하지의 신경전도검 사에서 다발신경병증에 해당하는 소견을 보였다(Table 1). Paraneoplastic vasulitis의 감별을 위해 시행한 혈액검사에 서 Paraneoplastic $\mathrm{Ab}$ 는 확인되지 않았고, 뇌, 흥부 및 복부 영상에서 악성종양 혹은 육아종을 시사하는 소견은 관찰되 지 않았다. 뇌척수액검사와 신경 생검 검사는 환자의 거부로 인하여 시행하지 못하였다. 따라서 혈액검사에서 $\mathrm{ESR}, \mathrm{CRP}$, $\mathrm{WBC}$ 상승이 동반된 P-ANCA 양성 소견, 신장침범, 그리고 다발신경병증을 보이는 AAV로 진단하였다.

진단 후 환자는 methylprednisolone $750 \mathrm{mg} /$ day pulse therapy를 3일간 시행하였다. 이후 4주간은 methylprednisolone $55 \mathrm{mg}$ /day 및 cyclophosphamide $75 \mathrm{mg} /$ day 을 유지하였고, 이후에는 methylprednisolone $30 \mathrm{mg}$ /day
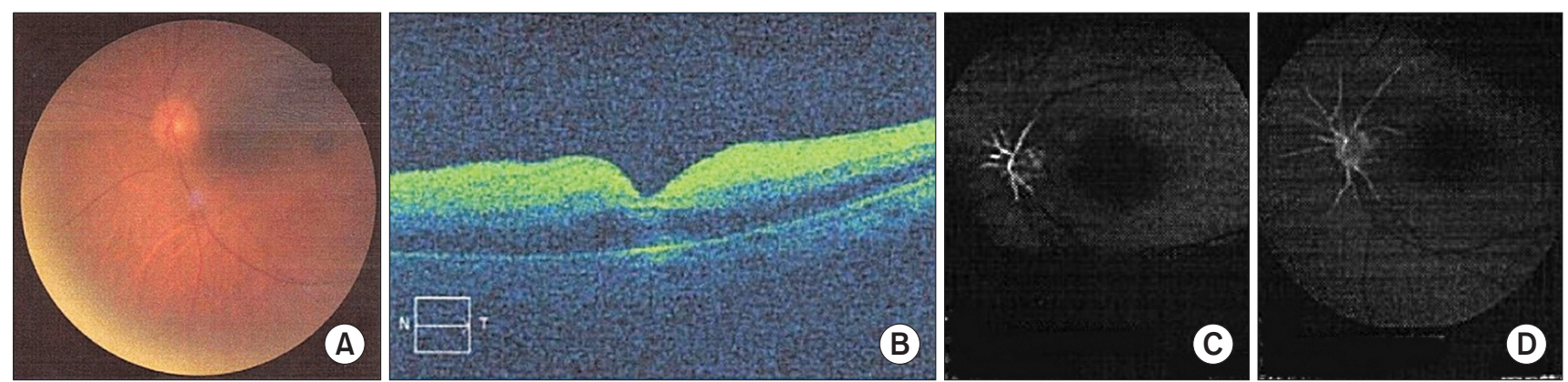

Fig. 1. Multimodal Images of left central retinal artery occlusion. (A) Fundus photography reveals macular whitening and cherry red spot. (B) Spectral domain optical coherence tomography (SD-OCT) reveals thickening and hyper-reflectivity of the inner retinal layers. (C) and (D) Fluorescein angiography (FA) reveals delayed retinal perfusion at early and late stages. 
Table 1. Findings of Nerve Conduction Study (Performed 6 Weeks after the Onset of Symptoms)

\begin{tabular}{clccc}
\hline \hline & & $\begin{array}{c}\text { Latency } \\
(\mathrm{ms})\end{array}$ & $\begin{array}{c}\text { Amplitude } \\
(\mathrm{mV})\end{array}$ & $\begin{array}{c}\text { Velocity } \\
(\mathrm{m} / \mathrm{s})\end{array}$ \\
\hline $\begin{array}{c}\text { Motor nerve } \\
\text { Lt. median }\end{array}$ & Wrist & 6.6 & 1.0 & - \\
& Elbow & 13.7 & 0.7 & 26 \\
Lt. ulnar & Wrist & 4.3 & 4.9 & - \\
& Below elbow & 9.6 & 4.9 & 45 \\
& Above elbow & 11.8 & 4.9 & 53 \\
Both tibial & Ankle & - & 0.0 & - \\
& PF & - & 0.0 & - \\
Both peroneal & Ankle & - & 0.0 & - \\
(EDB) & FH & - & 0.0 & - \\
& PF & - & 0.0 & - \\
\hline \hline & & Latency & Amplitude & \\
& & $(\mathrm{ms})$ & $(\mu \mathrm{V})$ & \\
\hline Sensory nerve & & & & \\
Lt. median & Wrist & - & 0.0 & - \\
& Palm & - & 0.0 & - \\
Lt. Ulnar & Wrist & 3.9 & 9.6 & 33 \\
Both sural & Ankle & - & 0.0 & - \\
\hline
\end{tabular}

PF: popliteal fossa, FH: fibular head, EDB: extensor digitorum brevis

및 cyclophosphamide $50 \mathrm{mg} /$ day로 감량하여 4달 후 퇴원 시까지 약을 유지하였다.

환자는 Pulse therapy 다음날부터 BUN 및 creatinine 수치의 호전을 보이기 시작하여, 일주일 후 혈액 검사에서 BUN $44.0 \mathrm{mg} / \mathrm{dL}$, creatinine $1.65 \mathrm{mg} / \mathrm{dL}$ 로 호전을 보였 다. 치료 시작 4주 후 근력등급은 양측 상지 원위부 Fair+ grade, 양측 하지 근위부 Fair grade, 우측 하지 원위부 Fairgrade로 호전을 보였다. 좌측 하지 원위부의 근력 향상은 관 찰되지 않아 좌측 고정형 발목 보조기를 착용하고 근력 향상 및 보행에 대한 지속적인 재활치료를 시행하였다. 치료 시작 10 주 후에는 최소 보조 하에 보행 가능한 정도의 기능적 회 복을 보였으며, 근력등급은 양측 하지 근위부 Fair+ grade로 호전을 보였고, 이외의 근력 등급에는 변화가 없었다. 같은 시기에 신경전도검사 및 침근전도 추적 검사를 시행 하였으 며 신경전도검사에서는 증상 발생 6주에 시행한 초기 검사 와 비교하여 뚜렷한 변화는 없었고, 침 근전도 검사상에서는 양측 상지의 정중신경과 척골 신경 그리고 양측 하지의 비골 신경과 경골신경의 지배 근육에서 비정상적 자발전위가 관 찰되었으며 근육을 활성화 시킬 때 운동단위활성전위가 관 찰되지 않거나 감소한 소견을 보였다(Table 2, 3).
Table 2. Findings of Nerve Conduction Study (Performed 4 Months after the Onset of Symptoms)

\begin{tabular}{|c|c|c|c|c|}
\hline & & $\begin{array}{l}\text { Latency } \\
\text { (ms) }\end{array}$ & $\begin{array}{l}\text { Amplitude } \\
(\mathrm{mV})\end{array}$ & $\begin{array}{c}\text { Velocity } \\
(\mathrm{m} / \mathrm{s})\end{array}$ \\
\hline \multicolumn{5}{|l|}{ Motor nerve } \\
\hline \multirow{2}{*}{ Lt. median } & Wrist & 6.35 & 1.5 & - \\
\hline & Elbow & 11.35 & 1.3 & 45 \\
\hline \multirow[t]{3}{*}{ Lt. ulnar } & Wrist & 4.40 & 6.1 & - \\
\hline & Below elbow & 8.50 & 6.0 & 47.6 \\
\hline & Above elbow & 10.50 & 5.7 & 50 \\
\hline \multirow[t]{2}{*}{ Rt. median } & Wrist & 5.10 & 3.9 & - \\
\hline & Elbow & 10.30 & 3.4 & 44.2 \\
\hline \multirow[t]{3}{*}{ Rt. Ulnar } & Wrist & 3.50 & 6.2 & \\
\hline & Below elbow & 7.70 & 5.7 & 52.4 \\
\hline & Above elbow & 9.50 & 5.3 & 55.6 \\
\hline \multirow[t]{2}{*}{ Both tibial } & Ankle & - & 0.0 & - \\
\hline & PF & - & 0.0 & - \\
\hline \multirow{4}{*}{$\begin{array}{l}\text { Both peroneal } \\
\text { (EDB) }\end{array}$} & Ankle & - & 0.0 & - \\
\hline & $\mathrm{FH}$ & - & 0.0 & - \\
\hline & $\mathrm{PF}$ & - & 0.0 & - \\
\hline & & $\begin{array}{l}\text { Latency } \\
\text { (ms) }\end{array}$ & $\begin{array}{c}\text { Amplitude } \\
(\mu \mathrm{V})\end{array}$ & \\
\hline \multicolumn{5}{|l|}{ Sensory nerve } \\
\hline \multirow[t]{2}{*}{ Both median } & Wrist & - & 0.0 & - \\
\hline & Palm & - & 0.0 & - \\
\hline Lt. Ulnar & Wrist & 4.15 & 6.2 & - \\
\hline Rt. Ulnar & Wrist & 3.95 & 9.3 & - \\
\hline Both sural & Ankle & - & 0.0 & - \\
\hline
\end{tabular}

PF: popliteal fossa, FH: fibular head, EDB: extensor digitorum brevis

\section{고 찰}

$\mathrm{AAV}$ 는 전세계적으로 150 만명 중 약 12 16명 정도의 유 병률을 보이며 ${ }^{2}$ 병인에 대하여 밝여진 바는 거의 없다. 미생 물과 인간단백질의 구조 유사성(molecular mimicry)이나 유전적 소인(genetic predisposition) 때문이라는 가설이 있 으나 지속적인 연구가 필요하다. ${ }^{3}$

혈관염의 잠재여부를 예측할 수 있는 인자로는 대표적 으로 $\mathrm{ANCA}$ 와 ESR의 상승 $(>100 \mathrm{~mm} / \mathrm{hr}$ )이 있다. 그 중 $\mathrm{ANCA}$ 는 그 종류에 따라 주로 침범하는 기관과 재발률의 차 이를 보이기 때문에 $\mathrm{ANCA}$ 의 종류가 진단적 도구로서 재조 명 받고 있고, 이를 기준으로 한 분류 체계가 필요하다는 주 장이 있다. ${ }^{3,4}$

$\mathrm{ANCA}$ 는 proteinase-3에 반응하는 세포질 항중성구 세포질항체(Cytoplasmic anti-neutrophil cytoplasmic antibody, C-ANCA)와 Myeloperoxidase에 반응하는 $\mathrm{P}-\mathrm{ANCA}$ 로 구분된다. C-ANCA와 주로 관련된 혈관염으 로는 GPA가 있으며, 상기도를 주로 침범하여 부비동염이 
Table 3. Findings of Needle Electromyography (Performed 4 Months after the Onset of Symptoms)

\begin{tabular}{|c|c|c|c|c|c|c|c|c|}
\hline & \multirow{2}{*}{ Muscles } & \multirow{2}{*}{ Nerves } & \multicolumn{3}{|c|}{ Spontaneous activity } & \multicolumn{3}{|c|}{ Motor unit potential } \\
\hline & & & $\mathrm{FP}$ & PSW & CRD & LMUP & PMUP & $\mathrm{RP}$ \\
\hline \multirow[t]{4}{*}{ Lt. upper } & FCR & Median & - & - & - & - & - & - \\
\hline & FCU & Ulnar & - & - & - & - & $1+$ & Reduced \\
\hline & FDI & Ulnar & - & ++ & - & - & - & Reduced \\
\hline & APB & Median & - & ++ & - & - & - & Reduced \\
\hline \multirow[t]{6}{*}{ Lt. lower } & G.medius & SGN & - & - & - & - & - & - \\
\hline & G.maximus & IGN & - & - & - & - & - & - \\
\hline & VM & Femoral & - & - & - & - & - & - \\
\hline & $\mathrm{TA}$ & Deep peroneal & - & + & - & - & - & NR \\
\hline & GCM & Tibial & - & + & - & - & - & NR \\
\hline & EHL & Deep peroneal & - & - & - & - & - & NR \\
\hline \multirow[t]{4}{*}{ Rt. upper } & FCR & Median & - & - & - & + & - & Reduced \\
\hline & FCU & Ulnar & - & - & - & - & - & - \\
\hline & FDI & Ulnar & - & - & - & - & - & - \\
\hline & APB & Median & - & + & - & - & - & Reduced \\
\hline \multirow[t]{6}{*}{ Rt. lower } & G.medius & SGN & - & - & - & - & - & - \\
\hline & G.maximus & IGN & - & - & - & - & - & - \\
\hline & VM & Femoral & - & - & - & - & - & - \\
\hline & $\mathrm{TA}$ & Deep peroneal & - & + & - & - & + & SMUP \\
\hline & GCM & Tibial & - & + & - & - & - & NR \\
\hline & $\mathrm{EHL}$ & Deep peroneal & - & - & - & - & - & NR \\
\hline
\end{tabular}

FP: fibrillation potential, PSW: positive sharp wave, CRD: complex repetitive discharge, LMUP: large motor unit action potential, PMUP: polyphasic motor unit action potential, RP: recruitment pattern, NR: no response, SMUP: single motor unit action potential, FCR: flexor carpi radialis, FCU: flexor carpi ulnaris, FDI: flexor digitorum interosseous, APB: abductor pollicis brevis, G.medius: gluteus medius, G.maximus: gluteus maximus, VM: vastus medialis, TA: tibialis anterior, GCM: gastrocnemius, EHL: extensor hallucis longus, IGN: inferior gluteal nerve, SGN: superior gluteal nerve

나 비강 삼출(nasal discharge)이 흔하고, 청력 소실이나 객 혈을 유발할 수 있다. 또한 조직학적으로 육아종성 병변을 일으키는 것이 특징적이다. P-ANCA와 관련성이 높은 질 환으로는 MPA와 eGPA가 있다. 본 증례와 같이 MPA는 신 장침범이 매우 흔하고, $\mathrm{GPA}$ 와 달리 육아종성 병변은 관찰 되지 않으며, 발열이나 발진 등의 전신증상, 피부병변, 복 통 등이 동반될 수 있다. eGPA의 경우 척스트라우스 증후 군으로 더 잘 알려져 있으며, 천식과 혈액내 호산구증, 호 흡기계 증상, 코곁굴병변, 혈관 주위 호산구 침윤을 특징으 로 한다. ${ }^{4} \mathrm{C}-\mathrm{ANCA}$ 는 $80 \%$ 이상에서 눈, 귀, 목이나 폐의 침 범을 우선적으로 보이는 반면, $\mathrm{P}-\mathrm{ANCA}$ 의 경우 말초신경 병증을 흔하게 보이고 $80 \%$ 이상의 경우에 신장침범이 발 생하는데 신장 생검에서 $\mathrm{AAV}$ 의 특징적인 소견인 pauciimmune crescentic glomerulonephritis가 관찰된다. 5,6 Crescentic glomerulonephritis는 RPGN과 동의어로서 pauci-immune crescentic glomuerulonephritis, antiGBM glomerulonephritis, 그리고 immune complex glomerulonephritis의 3가지 형태로 분류되는데 pauciimmune crescentic glomerulonephritis는 AAV의 특징 적인 소견이다. 본 증례는 신장 생검에서 pauci-immune crescentic glomerulonephritis가 관찰되었고 P-ANCA의 상승이 혈액검사상 확인되었으며 임상적으로 코나 부비동, 목의 침범이 동반되지 않아 $\mathrm{AAV}$ 중에서도 $\mathrm{MPA}$ 로 진단을 할 수 있었다. ${ }^{7,8}$

$\mathrm{AAV}$ 는 신경손상을 유발할 수 있으며 본 증례에서도 환자 는 양측 하지의 감각이상과 근위약과 같은 신경증상을 먼 저 호소하였다. $\mathrm{ANCA}$ 는 중성구를 활성화하고 활성산소 를 생산하여 혈관내피의 손상을 유발한다. ${ }^{9}$ 신경혈관(vasa nervorum)에 염증세포침윤으로 인한 허혈이 발생하면 말 초신경의 손상을 야기한다. 이는 급성 혹은 아급성의 진 행 경과를 보일 수 있고 주로 하지의 원위부에서 시작하 나, 비대칭적이며 신경 길이에 의존적이지 않은 침범을 보 이는 것이 특징적이다. 증상 초기에는 주로 다발홑신경염 (mononeuritis multiplex)을 유발하지만 본 환자의 경우처 럼 일부에서는 증상 초기부터 비대칭성 혹은 대칭성의 다발 신경병증이 결합되어 진단을 어렵게 만들 수 있다. ${ }^{4,5}$

$\mathrm{MPA}$ 는 주로 소혈관에서 괴사성 혈관염(necrotizing vasculitis)을 일으키며, 신장침범이나 신경침범을 흔하게 동반한다. 하지만, $\mathrm{AAV}$ 관련하여 편측 눈의 망막동맥폐쇄 가 동반된 증례는 보고된 바가 매우 드물다. $\mathrm{AAV}$ 가 혈전증 
과 관련이 되어 있다는 사실은 보고되고 있으나, 대부분이 심부정맥혈전증이며, 이 또한 기전에 대하여는 알려진 바 가 없었다. 이에 대해 최근에는 혈관염, 특히 $\mathrm{MPA}$ 와 관련하 여 NETs (Neutrophil Extracellular Traps)에 의한 혈전증 에 대한 연구가 진행되고 있다. 이는 $\mathrm{ANCA}$ 에 의해 발생한 호중구의 과활동(overactivity)이 혈소판응집을 유발하는 것 으로, $\mathrm{MPA}$ 환자의 신장 혈관 및 심부정맥혈전증 환자의 혈전 내 부검 소견에서도 NETs가 다량 관찰된 점이 이를 뒷받침 하고 있다. ${ }^{10}$ 망막동맥 폐쇄를 유발할 수 있는 가장 흔한 원 인은 색전증으로 특히 경동맥 기원의 죽상동맥경화 플라그 (atherosclerotic plaque)가 가장 흔하며 그밖에도 심혈관 계 기원의 색전증도 흔한 원인인데, 본 증례의 경우 심초음 파, 뇌자기공명검사 등을 시행하였으나, 특이사항은 관찰되 지 않았다.

본 증례는 편측 망막중심동맥 폐쇄라는 매우 드문 합병증 과 함께 토리콩팥염이 동반된 혈관염성 신경병증의 예이다. 급성 또는 아급성의 감각 저하와 근력저하가 있으면서 신장 침범 증상, 시력의 변화 등의 전신 증상이 동반되는 경우에 는 혈관염성 신경병증의 가능성을 생각하여야 한다. 또한 망 막 중심동맥 폐쇄는 응급처치를 요하는 질환으로, 혈관염의 경우에는 망막중심동맥 폐쇄가 동반될 수 있다는 점을 염두 에 두고 시력의 변화시 빠른 진단이 필요하다. 본 증례에서 는 하지의 감각이상 및 근력 저하 발생 초기에 신경전도검사 및 침근전도 검사가 이루어지지 않아 다발신경병증의 진단 과 치료가 늦어졌다. 신경증상이 있을 때에는 신경전도검사 및 침근전도 검사를 시행하여 신경손상의 유무를 확인하는 것이 빠른 진단과 치료에 도움이 될 것으로 보인다.

\section{References}

1. McKinney EF, Willcocks LC, Broecker V, Smith KGC: The immunopathology of ANCA-associated vasculitis. Semin Immunopathol 2014: 36: 461-478

2. Watts RA: Classification, epidemiology and clinical subgrouping of antineutrophil cytoplasmic antibody (ANCA)associated vasculitis. Nephrol Dial Transplant 2015: 30 Suppl 1: i14-i22

3. Cornec D, Cornec-Le Gall E, Fervenza FC, Specks U: ANCAassociated vasculitis-clinical utility of using ANCA specificity to classify patients. Nat Rev Rheumatol 2016: 12: 570-579

4. Park DY, Kim JY: Clinical and Electrodiagnostic Characteristics of Vasculitic Neuropathy. J Korean Assoc EMG Electrodiagn Med 2015: 17: 1-6

5. Lionaki S: Classification of antineutrophil cytoplasmic autoantibody vasculitides: the role of antineutrophil cytoplasmic autoantibody specificity for myeloperoxidase or proteinase 3 in disease recognition and prognosis. Arthritis Rheum 2012: 64: $3452-3462$

6. Syed R, Rehman A, Valecha G, El-Sayegh S: Pauci-Immune Crescentic Glomerulonephritis: An ANCA-Associated Vasculitis. BioMed Res Int 2015: 2015: 402826

7. Sunderkötter CH, Zelger B, Chen KR, Requena L, Piette W, Carlson JA, et al: Nomenclature of Cutaneous Vasculitis: Dermatologic Addendum to the 2012 Revised International Chapel Hill Consensus Conference Nomenclature of Vasculitides. Arthritis Rheumatol 2018: 70: 171-184

8. Liu LJ, Chen M, Yu F, Zhao MH, Wang HY: Evaluation of a new algorithm in classification of systemic vasculitis. Rheumatology 2008: 47: 708-712

9. Chen M, Kallenberg CG: ANCA-associated vasculitides--advances in pathogenesis and treatment. Nat Rev Rheumatol 2010: 6: 653-664

10. Nakazawa D, Tomaru U, Yamamoto C, Jodo S, Ishizu A: Abundant neutrophil extracellular traps in thrombus of patient with microscopic polyangiitis. Front Immunol 2012: 3: 333 